\title{
Review
}

\section{Lipid Metabolism and Glial Lipoproteins in the Central Nervous System}

\author{
Hideki HAYASHI \\ Priority Organization for Innovation and Excellence, Kumamoto University; \\ 1-1-1 Honjo, Kumamoto 860-8556, Japan. \\ Received January 24, 2011
}

\begin{abstract}
Lipoproteins in the central nervous system (CNS) are not incorporated from the blood but are formed mainly by glial cells within the CNS. In addition, cholesterol in the CNS is synthesized endogenously because the blood-brain barrier segregates the CNS from the peripheral circulation. Apolipoprotein (apo) $\mathrm{E}$ is a major apo in the CNS. In normal condition, apo $\mathrm{E}$ is secreted from glia, mainly from astrocytes, and forms cholesterol-rich lipoproteins by ATP-binding cassette transporters. Subsequently, apo E-containing glial lipoproteins supply cholesterol and other components to neurons via a receptor-mediated process. Recent findings demonstrated that receptors of the low density lipoprotein (LDL) receptor family not only internalize lipoproteins into the cells but also, like signaling receptors, transduce signals upon binding the ligands. In this review, the regulation of lipid homeostasis will be discussed as well as roles of lipoproteins and functions of receptors of LDL receptor family in the CNS. Furthermore, the relation between lipid metabolism and Alzheimer's disease (AD) is discussed.
\end{abstract}

Key words lipoprotein; central nervous system; low density lipoprotein receptor family; cholesterol; apolipoprotein E; Alzheimer's disease

\section{INTRODUCTION}

Functions of the central nervous system (CNS) are performed mainly by neurons and glia-primarily astrocytes, microglia and oligodendrocytes. It has been thought for a long time that glia only passively support neurons, but we now know that glia actively attend to assist in neuronal functions like synaptogenesis and neurotransmission. ${ }^{1)}$ Although it was believed that $c a .90 \%$ of the cells in the brain are glia and the rest of cells are neurons, Azevedo et al. recently reported that the numbers of neurons and non-neuronal cells (glia) are close to equal in human adult brain. ${ }^{2)}$ Brain is the most cholesterol-rich organ in the body, and cholesterol metabolism in the CNS is tightly regulated between neurons and glia. ${ }^{3-7)}$ Imbalances in the metabolism of lipids, especially cholesterol, are closely linked to the development of several neurodegenerative disorders such as Alzheimer's disease, ${ }^{8,9)}$ Niemann-Pick type C disease ${ }^{10)}$ and Smith-Lemli Opitz syndrome. ${ }^{11,12)}$ In this review the regulation of lipid metabolism and the roles of glial lipoproteins in the CNS will be discussed.

\section{LIPID HOMEOSTASIS IN THE CNS}

The system of lipid metabolism and transport in the CNS is different from that in peripheral tissues because the CNS is segregated from the peripheral circulation by the blood-brain barrier (BBB) ${ }^{13)}$ Although lipoprotein particles can cross the $\mathrm{BBB}$ in vivo in Drosophila, which has a functional BBB like that in vertebrates, ${ }^{14)}$ lipoproteins in the mouse, rat and human do not cross the BBB. Consequently, since labeled cholesterol peripherally administrated was not found in the CNS of mammals, ${ }^{15,16}$ cholesterol in the CNS is derived from de novo synthesis inside of the CNS. Furthermore, in the plasma of subjects who had liver transplantation the genotype of apolipoprotein (apo) E was that of the donor, whereas the subjects retained the own apo E genotype in the cerebrospinal fluid (CSF). ${ }^{17)}$ Moreover, lipoproteins in the CNS consist of only high density lipoprotein (HDL)-like par- ticles in contrast to the circulation which contains very low density lipoproteins (VLDL), low density lipoproteins (LDL) and HDL. It is known that the HDL-like particles in the CNS are secreted from glia (glial lipoproteins), mainly astrocytes and microglia, under normal conditions, ${ }^{18-20)}$ however lipoproteins can be secreted from neurons in vitro ${ }^{21,22)}$ and in vivo ${ }^{23)}$ under some specific conditions.

Unesterified cholesterol is the major sterol in the adult brain, and small amounts of desmosterol and cholesteryl ester are also present. The majority $(70-80 \%)$ of cholesterol in the adult brain is in myelin formed by oligodendrocytes. ${ }^{24)}$ Thus, the activity of cholesterol synthesis in the CNS is the highest during the myelinogenesis. After myelination, cholesterol synthesis continues at very low level in the CNS, and occurs mainly in astrocytes. ${ }^{5,13,24)}$ Neurons do not efficiently synthesize cholesterol and rely on external source of cholesterol from astrocytes ${ }^{25)}$ so that neurons take up cholesterol as lipoproteins via receptors of the members of LDL receptor family. Cholesterol associated with apo E-containing lipoproteins promotes synaptogenesis in CNS neurons, ${ }^{26)}$ and apo Econtaining lipoproteins derived from glia stimulate axonal growth of CNS neurons. ${ }^{27)}$ Members of LDL receptor family play important roles in the CNS and apo $\mathrm{E}$ is a common ligand for all members of the LDL receptor family. ${ }^{28-30)}$ It is reported that $L d l r^{--}$mice show a marked increase of apo E in the cortex and the $\mathrm{CSF}^{31)}$ compared to $\mathrm{Ldll}^{+/+}$mice. Moreover, conditional knockout of the low density lipoprotein receptor-related protein 1 (LRP1) in forebrain of mice also showed a significant increase in apo $\mathrm{E}$ and a significant decrease of cholesterol in the brain. ${ }^{32)}$ Thus, the LDL receptor and LRP1 seem to play the major role in the uptake of glia-derived apo E-containing lipoproteins in the CNS. Cholesterol incorporated into neurons in a receptor-mediated manner is hydroxylated to $24 S$-hydroxycholestero ${ }^{33,34)}$ in a reaction catalyzed by cholesterol 24-hydroxylase (encoded by the CYP46A1 gene), whose localization is restricted to large pyramidal neurons in various layers of the cortex, hippocampus and Purkinje cells in the cerebellum. ${ }^{35)}$ This oxysterol can cross the BBB, diffuse into the peripheral circula- 


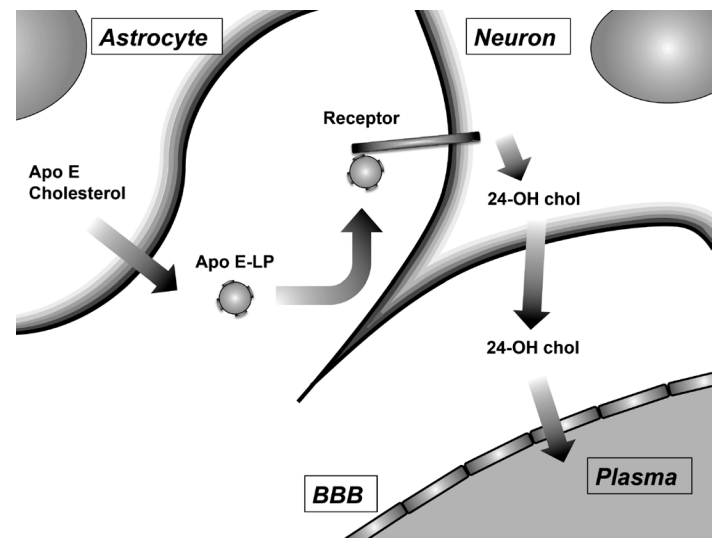

Fig. 1. Cholesterol Homeostasis in the Central Nervous System

Apo E and cholesterol are synthesized mainly in astrocytes and secreted as apo Econtaining lipoproteins (Apo E-LP). Apo E-LPs bind to receptors of the LDL receptor family (Receptor) and are incorporated into neurons. Excess cholesterol in neurons is converted into $24 S$-hydroxycholesterol (24-OH chol). This oxysterol diffuses from neurons, crosses the blood-brain barrier and is subsequently metabolized by the liver.

tion, be delivered to the liver and then be excreted into the bile. However, in the study with Cyp46a1 ${ }^{-/-}$mice $^{34)}$ this excretion pathway of cholesterol from the brain explained only ca. $50 \%$ of total cholesterol turnover, indicating that an additional, unidentified pathway for sterol excretion from the brain must exist. ${ }^{36)}$ As described above, lipid homeostasis in the CNS is closely regulated between neurons and glia (Fig. 1).

\section{LIPOPROTEIN FORMATION IN THE CNS}

ATP-binding cassette (ABC) transporters are important molecules for mediating lipid transport in the CNS, especially in the formation of apo E-containing lipoproteins, ${ }^{37,38)}$ the most abundant lipoproteins in the CNS. ${ }^{7)}$ ABCA1, ABCG1 and ABCG4 are highly expressed in the brain, i.e. in neurons and glia. ${ }^{37,39,40)}$ Experiments with $\mathrm{Abcal}^{-1-}$ mice demonstrated not only significant reduction of cholesterol in the CSF but also a reduction of apo E in the CSF and brain parenchyma. ${ }^{41,42)}$ It has recently been reported that neuronand glia-specific ABCA1 deficiency decreased levels of cholesterol and apo $\mathrm{E}$ in the brain and promoted the uptake of esterified cholesterol from plasma HDL into the brain. ${ }^{43}$ Mice specifically lacking ABCA1 in the brain also demonstrate alteration in motor activity and a reduction of excitatory synapses and synaptic vesicles. These experiments with ABCA1 knockout mice showed that ABCA1 is a crucial molecule for the formation of apo E-containing lipoproteins in the CNS.

ABCG1 is expressed in multiple tissues including the lung, kidney, liver, spleen, retina and brain, ${ }^{39,44)}$ whereas ABCG4 is specifically expressed in the CNS. ${ }^{39,45)}$ ABCG1 expression correlates more closely with cholesterol efflux to apo AI and apo $\mathrm{E}$ than does the expression of ABCA1 in cerebellar astrocytes. ${ }^{46)}$ Individual deficiency of ABCG1 or ABCG4 in mice showed essentially normal brain sterol levels, but $A b c g 1^{-1-} / A b c g 4^{-1-}$ mice demonstrated significant increases of some sterol intermediates - desmosterol, lathosterol, lanosterol and oxysterols - in the brain. ${ }^{40)}$ This study also revealed a defect in cholesterol efflux from astrocytes to HDL only when both of the ABCG transporters were elimi- nated. On the other hand, $A b c g 4^{-1-}$ mice, but not $A b c g 1^{-1-}$ mice, demonstrated a defect in associative fear memory. ${ }^{47)}$ In addition, ABCG4 is highly expressed in microglia surrounding amyloid plaques in Alzheimer's disease (AD) brains. ${ }^{48}$ ) Thus, these studies indicate that ABCG1 and ABCG4 share some functions for sterol efflux, but ABCG4 might more closely relate to brain function.

\section{LIPOPROTEINS IN THE CNS}

The CSF contains apos similar to those in plasma. For example, apo E, apo AI, apo AII, apo J, apo CI, apo CII, apo CIII and apo D, but not apo B, are found in the CSF. ${ }^{49,50)}$ The concentration of apo AI and apo $\mathrm{E}$ in the CSF is only ca. $0.5 \%$ and $5-15 \%$, respectively, of that in plasma. ${ }^{51,52)}$ The ratio of other apolipoproteins (apo J, apo CI, apo CII, apo CIII) in the CSF to plasma is $2-5 \%{ }^{50)}$ Primary cultures of astrocytes secrete apo E, apo $\mathrm{J}$ and apo D, but not apo AI. ${ }^{53)}$

Apo $\mathrm{E}$ is the most abundant apo in the CNS and plays a central role in lipid metabolism in the nervous system. Apo E is secreted mainly from astrocytes, but neurons and microglia can express apo E under conditions such as injury. ${ }^{53,54)}$ The synthesis of apo E in glia is dramatically up-regulated in response to nerve injury of the CNS and peripheral nervous system. ${ }^{55-57)}$ In addition, smooth muscle cells of large blood vessels, cells surrounding small vessels, and cells in the choroid plexus also express apo $\mathrm{E}$ in the brain. ${ }^{23)} \mathrm{A}$ deficiency of apo E causes neurodegeneration in the CNS during aging $^{58)}$ and apo E-deficient mice exhibit impairment of learning and memory. ${ }^{59-61)}$ It is also reported that apo E mediates the neuroprotective effect of estrogen against global ischemia in mice ${ }^{62)}$ and that the hippocampus in Apo $E^{-/-}$ mice has increased susceptibility to endoplasmic reticulum (ER) stress induced by transient ischemia. ${ }^{63)}$ In addition, impairment of cholesterol biosynthesis in the brain and reduction of the secretion of apo E-containing lipoproteins from astrocytes were found in several animal models and human subjects of Huntington's disease. ${ }^{64,65)}$ Apo E is a ligand for all receptors of the LDL receptor family that are expressed in the CNS. ${ }^{28-30)}$ We have demonstrated that apo E-containing lipoproteins from glia promote axonal extension mediated by receptors of the LDL receptor family in the CNS neurons. ${ }^{27}$ ) Subsequent studies indicated that the stimulation of axonal extension by apo E-containing lipoproteins is mediated by the LRP1 and requires the presence of sphingomyelin in the apo E-containing lipoproteins. ${ }^{66)}$ Apo E not only plays major roles in lipid metabolism in the $\mathrm{CNS}^{7,67)}$ but also acts as a ligand for receptors in neurons. ${ }^{28)}$ Furthermore, apo E performed as an anti-inflammatory molecule through the LDL receptor and LRP1 on glia that were activated by amyloid $\beta$ protein. ${ }^{68)}$ We have also demonstrated that apo E-containing glial lipoproteins protect CNS neurons from apoptosis via a signaling pathway induced by LRP1 and involving phospholipase $\mathrm{C} \gamma 1$, protein kinase $\mathrm{C} \delta$ and glycogen synthase kinase $3 \beta .^{69,70)}$ The evidence described above suggests the remarkable importance of apo E in the CNS (Fig. 2). Since apo E is closely related to the development of late onset of Alzheimer's disease, this topic will be discussed below.

Apo J, also called clusterin, is a multifunctional heterodimeric glycoprotein with an almost ubiquitous distribu- 


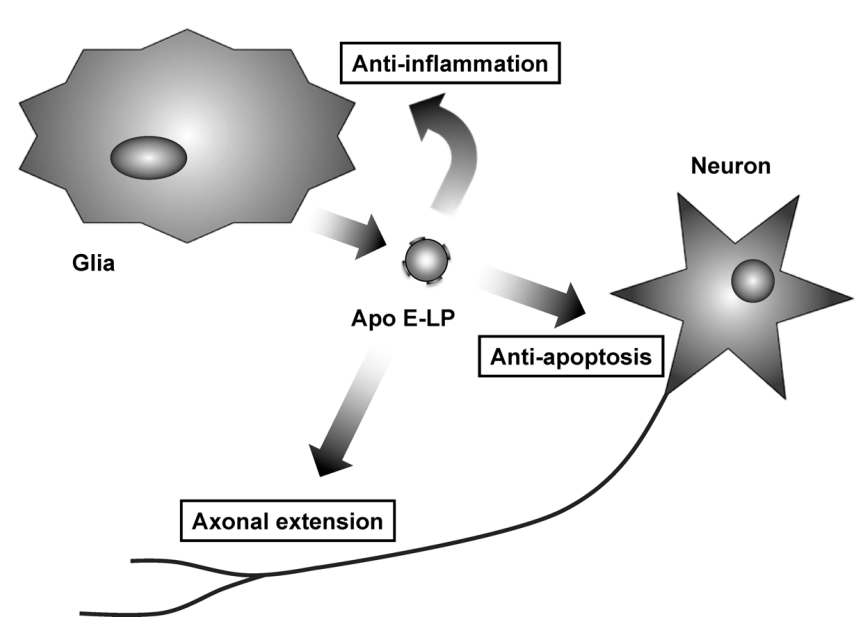

Fig. 2. Effects of Apo E-Containing Lipoproteins in Neurons and Glia

Apo E-containing lipoproteins (Apo E-LP) secreted from glia have an anti-inflammatory effect on glia, perform as an anti-apoptotic molecule on neurons and promote axonal extension of neurons via the members of LDL receptor family.

tion, but this apo is highly expressed in brain and liver. ${ }^{71}$ ) Fagan et al. reported that apo J-containing lipoproteins in the CNS are small, lipid-poor particles that are secreted from astrocytes. ${ }^{72)}$ In the CSF, apo $\mathrm{J}$ and apo $\mathrm{E}$ are present on distinct lipoprotein particles. The expression levels of apo $\mathrm{J}$ mRNA and protein are up-regulated during neurodegeneration in kinate-treated, ${ }^{73)}$ chemical-lesioned ${ }^{74)}$ and toxic protein-injected brains. ${ }^{75)}$ Although Apo $J^{-/-}$mice did not show remarkable changes in the development and the morphology of the $\mathrm{CNS}^{76)}$ a deficiency of apo J exacerbated the severity of ischemic injury in the brain ${ }^{77)}$ and the susceptibility to axotomy-induced death in motor neurons. ${ }^{78)}$ These findings suggest that apo $\mathrm{J}$ is a neuroprotective molecule. On the other hand, the absence of apo $\mathrm{J}$ reduced neuronal death after hypoxic-ischemic injury in vivo and in vitro. ${ }^{79)}$ It has also been reported that a truncated form of apo J, formed by irradiation in vitro, translocates to the nucleus and acts as a cell death signal. ${ }^{80}$ Thus, apo J appears to have both pro- and antiapoptotic properties in the brain. Apo $\mathrm{J}$ also promotes proliferation of primary astrocytes by activation of the extracellular signal-regulated kinase signaling pathway. Since astrocytes express megalin, which is a member of the LDL receptor family and a receptor for apo $\mathrm{J}$, this proliferative effect of apo $\mathrm{J}$ might be mediated by megalin. ${ }^{81,82)}$

Apo D is synthesized in oligodendrocytes and astrocytes of the $\mathrm{CNS}^{83)}$ and shows neurotrophic and synaptogenic effects in dorsal root ganglion neurons in vitro. ${ }^{84)}$ The levels of apo $\mathrm{D}$ are increased in the pre-frontal cortex of $\mathrm{AD}$ patients $^{85)}$ and in brains of an animal model of Niemann-Pick type $\mathrm{C}$ disease, ${ }^{86)}$ without any change in the amount of apo $\mathrm{E}$. The mRNA level and immunoreactivity of apo D is up-regulated in oligodendrocytes and astrocytes in the peri-infarct area of experimental stroke, ${ }^{87,88)}$ and the level of apo E is also increased in this area of animal stroke model. ${ }^{89)}$ The level of apo D in the brain of apo E knockout mice was increased 50fold compared to that in wild type mice. ${ }^{90)}$ These experiments indicate that the apo D and apo E might have some compensatory, but not completely overlapping, roles for each other.

Apo AI is present in the CSF but is not produced within the CNS. Although the mechanism of transport of this apo into the CNS is unknown, small amounts might cross the BBB from the plasma. ${ }^{91)}$ Apo AI-containing lipoproteins in the CSF are HDL-like particles similar in density and size to the apo E-containing lipoproteins. However, these apos are primarily located on separate populations of lipoprotein particles. ${ }^{51)}$ Recent studies with genetic modifications of apo AI in AD mouse models demonstrate that apo AI performs protective roles in memory and AD pathology. ${ }^{92,93)}$ Furthermore, a remarkable reduction of apo AI has been shown in the CSF and brain of schizophrenia patients. ${ }^{94)}$ Thus, apo AI incorporated into the brain from the circulation might play important roles in the CNS.

\section{LDL RECEPTOR FAMILY MEMBERS IN THE CNS}

The members of LDL receptor family are widely expressed in the CNS. The seven core members-LDLR, VLDLR, apoER2/LRP8, LRP4/MEGF7, LRP1, LRP1B and megalin/LRP2 - and a subgroup of three members-LRP5, LRP6 and SorLA/LR11 - are all expressed in mammals. Apo $\mathrm{E}$ can bind as a ligand to all members of LDL receptor family. ${ }^{28-30)}$

LRP1 is a multifunctional endocytotic and signaling receptor. ${ }^{95-97)}$ In neurons, LRP1 interacts with the $N$-methyl-Daspartate (NMDA) receptor at synapses and participates $\mathrm{Ca}^{2+}$ signaling, indicating that LRP1 can modulate neurotransmission in the CNS. ${ }^{98,99)}$ A deficiency of LRP1 in neurons induces activation of caspase 3, a decrease of Akt phosphorylation and a decrease in the level of the insulin receptor, as well as the progression of apoptosis. ${ }^{100)}$ Binding of ligands, such as tissue-type plasminogen activator or $\alpha 2$ macroglobulin, to LRP1 in neurons transactivates the Trk receptor by activation of Src family kinase, suggesting that these ligands may have neurotrophic activity. ${ }^{101)}$ We have also reported that another ligand for LRP1, apo E associated with lipid, induces a strong anti-apoptotic effect and protects against neurodegeneration through an intracellular signaling pathway. ${ }^{69,70)}$ Global knockout of LRP1 in mice causes death during early embryonic development. ${ }^{102)}$ The knockout of LRP1 specifically in neurons of mice caused hyperactivity and motor deficits including tremor and dystonia. ${ }^{99)}$ Furthermore, forebrain neuron-specific knockout of LRP1 in mice had significant reductions of cholesterol, sulfatide, galactosylceramide and triacylglycerols in the brain and showed dendritic spine and synapse loss in neurons, neurodegeneration and memory defect. These observations indicate that LRP1 has a critical role in lipid metabolism and neuronal functions in the brain. ${ }^{103)}$

ApoER2 and VLDLR are the first receptors of the LDL receptor superfamily to be clearly identified as signaling receptors. ${ }^{104,105)}$ These receptors perform major roles in the CNS during development. Deficiency of both apoER2 and VLDLR in mice disrupts cortical and cerebellar cell layers and results in ataxia by affecting neuronal cell migration, although single deficiency of these receptors shows a minor phenotype compared to double deficiency. ${ }^{106)}$ The extracellular protein Reelin is a ligand for both apoER2 and VLDLR $^{107)}$ and induces phosphorylation of Dab1, which is an adaptor protein that interacts with NPxY motifs in the Cterminal tails of the receptors. The C-terminal tail of apoER2 interacts with the NMDA receptor via PSD-95, an intracellu- 
lar scaffolding protein in post-synaptic membranes, implying that Reelin can influence synaptic activity. Intriguingly, apo $\mathrm{E}$ inhibits this interaction between Reelin and the apoER2 and the VLDLR. Detailed molecular mechanisms of the reactions occurring downstream of the receptors are substantially reviewed elsewhere. ${ }^{29,104,105,108-110)}$ It has recently been reported that thrombospondin-1 is also a ligand for apoER2 and VLDLR, thereby inducing Dab1 phosphorylation and leading to integration of the neuronal precursor chain. ${ }^{111}$ )

Megalin is a receptor for apo $\mathrm{J}^{112)}$ as well as apo $\mathrm{E}$ and is expressed in the cerebral vascular endothelium, choroid epithelium, ${ }^{113)}$ astrocytes ${ }^{82)}$ and neurons ${ }^{114)}$ of the CNS. Knockdown of megalin causes a significant increase in neurite branching in primary hippocampal neurons. ${ }^{115)}$ Megalin-null mice die perinatally due to insufficient respiration and developmental abnormalities in the lung. A deficiency of megalin causes severe abnormalities of the forebrain, a lack of the olfactory bulb in brain, and malformation of facial structures. ${ }^{116)}$ This phenotype could be caused by cellular starvation of cholesterol and fat-soluble molecules like vitamins during development, because megalin is an endocytic receptor. In human subjects, mutations in megalin cause Donnai-Barrow syndrome, which exhibits similar phenotypes to those in the mouse model. ${ }^{117)}$

SorLA/LR11 is a mosaic protein identified as a member of the LDLR family as well as the Vps10p domain receptor family. SorLA has roles in protein transport and signal transduction. ${ }^{118,119)}$ SorLA is abundantly expressed in the brain, liver and adrenal glands ${ }^{120)}$ and in the rat and human brain is exclusively localized to neurons. ${ }^{121)}$ In sympathetic neurons, SorLA is restricted to cell bodies/proximal axons and was undetectable in distal axons. ${ }^{122)}$ It has been demonstrated that endogenous SorLA and LRP1 interact in perinuclear compartments of primary cultured neurons. ${ }^{123)}$ Since SorLA is recognized as a sorting receptor, ${ }^{124)}$ this interaction between SorLA and LRP1 might affect the functions of LRP1 in neurons.

\section{LIPID METABOLISM AND AD}

$\mathrm{AD}$ is the most common form of dementia and a major health problem especially in developed countries. Whereas clear mechanisms underlying the development of AD are still unknown, many studies support a linkage between lipid metabolism and AD. ${ }^{125-129)}$

The relationship between apo $\mathrm{E}$ and $\mathrm{AD}$ has been extensively investigated ${ }^{30,130-134)}$ because inheritance of the $\varepsilon 4$ allele of apo $\mathrm{E}$ is the most powerful genetic risk factor for the development of late-onset AD. ${ }^{135)}$ In humans, the three common isoforms of apo E-apo E2, apo E3 and apo E4 - are encoded by three alleles, $\varepsilon 2, \varepsilon 3$ and $\varepsilon 4$, respectively. Differences among these three isoforms consist of only one or two amino acids at residue 112 or 158: apo E2 (cys112, cys158), apo E3 (cys112, $\arg 158)$ and apo E4 (arg112, $\arg 158)$. However, the $\varepsilon 4$ allele of apo E gene brings a higher risk, and $\varepsilon 2$ allele a lower risk, for the development of $\mathrm{AD}(\varepsilon 4>$ $\varepsilon 3>\varepsilon 2) .{ }^{136)}$ Histological studies demonstrate that the density of amyloid plaques, one of hallmarks of $\mathrm{AD}$ pathology, correlate with the gene dose of Apo E4 allele. ${ }^{137,138)}$ Recent studies using a positron emission tomography radioligand demonstrated that the level of fibrilar amyloid $\beta$ peptide $(\mathrm{A} \beta)$ burden showed an Apo E4 allele dose-dependent increase in cognitively normal subjects. ${ }^{139)}$ The association between lipidated-apo E4 and $\mathrm{A} \beta$ occurs to a far lesser extent than with lipidated-apo E2 and -apo E3 (apo E2>apo E3 $\gg$ apo E4). ${ }^{140,141)}$ This is in reverse order of the risk for AD. Thus, it is considered that apo E might play an important role in protecting neurons by clearing out $\mathrm{A} \beta$ from the brain. For example, astrocyte-derived apo E2 and apo E3 complexed with $\mathrm{A} \beta$ are cleared from the brain at a substantially faster rate than apo E4 complexed with $\mathrm{A} \beta{ }^{\left.1{ }^{142}\right)}$ The transport of the apo E$\mathrm{A} \beta$ complex is mediated by LRP1 at BBB. ${ }^{143-145)}$ In support of the role of apo E4 in AD, we have shown that glia-derived apo E3-containing lipoproteins are more protective against apoptosis of CNS neurons in vitro than are glia-derived apo E4-containing lipoproteins, and that the protection occurs via an LRP1 mediated signaling pathway ${ }^{70)}$ (Fig. 3).

As is the case for apo E, apo $\mathrm{J}$ can also associate with $\mathrm{A} \beta^{146)}$ and is found in senile plaques of $\mathrm{AD}$ brains. ${ }^{147)}$ The levels of apo $\mathrm{J}$ protein and mRNA are increased in the hippocampus and cortex of AD brain. ${ }^{148,149)}$ In addition, apo J protects hippocampal neurons in vitro from $\mathrm{A} \beta$ induced neurotoxicity but not from hydrogen peroxide-induced stress or kainic acid excitotoxicity. ${ }^{150)}$ Megalin is a receptor for apo $\left.\mathrm{J},{ }^{112}\right)$ and this receptor also interacts with amyloid precursor protein (APP) and its adaptor protein FE65 in hippocampal neurons. ${ }^{115)}$ Apo $\mathrm{J}$ can remove $\mathrm{A} \beta$ from the CSF through the $\mathrm{BBB}$ to the peripheral circulation via megalin. ${ }^{113)}$ Thus, apo $\mathrm{J}$ seems to have a protective role in AD pathology and neurotoxicity. On the other hand, when the mouse model of AD (APP V717F) was bred with Apo $J^{-1-}$ mice, the deficiency of apo $\mathrm{J}$ decreased the neuritic dystrophy associated with amyloid plaques and induced significant reduction of $\mathrm{A} \beta$ deposition in vivo. ${ }^{151)}$ A genome-wide association study has shown that variations in the apo $\mathrm{J}$ gene are associated with the risk of late-onset AD. ${ }^{152)}$ Thus, whereas apo J appears to play important roles in the development of $\mathrm{AD}$, these functions and the underlying mechanisms remain unclear.

The mRNA level of apo D is increased during aging in control mice and further increased in the corpus callosum and hippocampus of aged-AD model mice (APP V717F). ${ }^{153)}$ The protein amount of apo $\mathrm{D}$ is also increased in the CSF

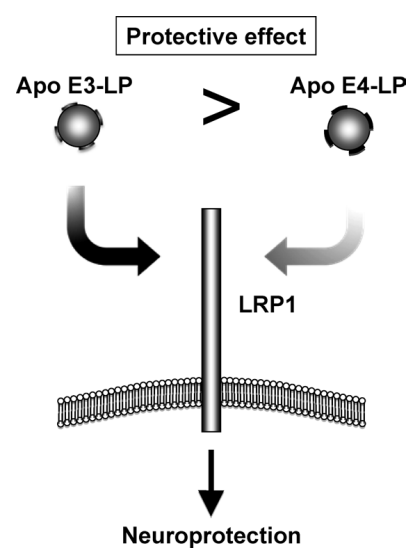

Fig. 3. Protective Effect of Apo E-Containing Glial Lipoproteins on Neurons

Apo E3-containing glial lipoproteins are more protective against apoptosis of neurons than are apo E4-containing glial lipoproteins via an intracellular signaling pathway of LRP1. 
and brain of elderly and AD patients, ${ }^{154-157)}$ independently of the amount of apo E. ${ }^{85)}$ An immunohistochemical study shows that apo E is co-localized with the amyloid core, but apo $\mathrm{D}$ is detected around and near the plaques, ${ }^{158)}$ indicating that apo $\mathrm{D}$ might have a role in $\mathrm{A} \beta$ deposition independent of apo E. Several studies have demonstrated that polymorphisms in the apo D gene are associated with an increase of the risk of $\mathrm{AD}$ in Chinese, Finnish and African-American subjects. ${ }^{159-161)}$

Apo AI deficiency in a mouse model of AD (APP V717F) reduced plasma and brain cholesterol levels but not AD pathology in the brain. ${ }^{162)}$ However, it was recently reported that over-expression of human apo AI preserves cognitive function and attenuates neuroinflammation and cerebral amyloid angiopathy in a mouse model of AD. ${ }^{92)}$ In addition, a deficiency of apo AI in AD model mice (APPSwe/PS1 $\Delta \mathrm{E} 9$ ) accelerated the memory deficits and caused significant cerebral amyloid angiopathy. ${ }^{93)}$ Variation in the apo AI gene might also influence the age of onset and the risk of AD. ${ }^{163)}$ Thus, some studies indicated that apo AI is a protective molecule against AD.

The liver $\mathrm{x}$ receptors (LXRs) are oxysterol-activated nuclear receptors. Their target genes (e.g. Apo E, ABCA1 and ABCG1) are associated with lipid metabolism and transport. ${ }^{164)}$ Lack of either $\operatorname{LXR} \alpha$ or $\operatorname{LXR} \beta$ increases amyloid plaque deposition in AD model mice (APPSwe/PS1 $\Delta \mathrm{E} 9) .{ }^{165)}$ Moreover, the LXR agonist TO901317 decreased A $\beta$ levels and amyloid plaques and improved memory loss in AD models (Tg2576 and APP23). ${ }^{166,167)}$ Furthermore, another LXR agonist GW3965 reduced A $\beta$ levels and amyloid plaques, enhanced apo E expression, and improved memory deficits in a mouse model of AD (Tg2576). ${ }^{168)}$

Recently, a relationship has been suggested between SorLA and $\mathrm{AD}^{124,169,170)}$ because SorLA gene variants are associated with sporadic AD. ${ }^{171)}$ When the AD model mice (APPSwe/PS1 $1 \mathrm{E} 9$ ) were crossed with SorLA-deficient mice, $\mathrm{AD}$ pathology occurred earlier that in the $\mathrm{AD}$ model mice expressing SorLA. ${ }^{172}$ Interestingly, the expression level of SorLA is decreased in sporadic AD but not in familial AD. ${ }^{173,174)}$ SorLA levels are also reduced in neurons of patients with mild cognitive impairment ${ }^{175)}$ and in the CSF of patients with late-onset AD. ${ }^{176)}$ SorLA regulates APP sorting in neurons and protects the neurons from amyloidgenic cleavage of APP by $\beta$-secretase at Golgi. ${ }^{177-180)}$ It is reported that the SorLA level is increased by administration of docosahexaenoic acid (DHA) in vitro (primary neurons) and in vivo (AD model Tg2576), ${ }^{181)}$ indicating that DHA might be beneficial for use against AD. However, the influence of DHA in AD is still controversial. ${ }^{182}$

LRP1 is localized on the abluminal side of the BBB and mediates the transcytosis of $\mathrm{A} \beta$ from the brain to the blood. ${ }^{144,145,183)}$ This LRP1-mediated $\mathrm{A} \beta$ clearance mechanism might be a crucial target for preventing AD. LRP1 also internalizes $\mathrm{A} \beta 42$ into neuronal cells resulting in the accumulation of $\mathrm{A} \beta$ in lysosomes, suggesting that the intracellular accumulation may be associated with neurotoxicity by $\mathrm{A} \beta{ }^{184)}$ Moreover, LRP1 interacts with APP in the intracellular secretory pathway and modulates APP metabolism in cells. ${ }^{185)}$ Whereas it is strongly suggested that ligands for LRP1, such as APP, $\alpha 2$-macroglobulin and apo E, are genetically linked to the increased risk and/or age of onset of
$\mathrm{AD},{ }^{135,186,187)}$ any genetic association of LRP1 with AD remains unclear. ${ }^{188-192)}$

The scavenger receptor class B type I (SR-BI) has been characterized as an HDL receptor and is expressed in microglia and astrocytes. ${ }^{193,194)}$ Reduction of SR-BI in a mouse model of AD (J20) induced a deterioration in learning and memory and promoted cerebral amyloid angiopathy as well as the deposition of fibrillar $A \beta$ in the hippocampus. ${ }^{195)}$ In addition, aged SR-BI knockout mice (over 20 months old) revealed an impairment of long-term potentiation in the hippocampus and deficits of recognition and spatial memories. ${ }^{196)}$

The CSF contains the phospholipid transfer protein (PLTP), which has been proposed to facilitate the transport of phospholipid for generation of mature lipoproteins. ${ }^{197,198)}$ PLTP is widely distributed in neurons and glia of the CNS ${ }^{199}$ ) and its activity is decreased in the CSF of AD patients. ${ }^{200)}$ The activity of cholesteryl ester transfer protein (CETP), which transfers cholesteryl ester and triacylglycerols between lipoproteins, has been detected in the CSF, ${ }^{201)}$ and CETP has been detected immunologically in human astrocytes. ${ }^{202)}$ However, rats, mice and some other species do not express CETP and the levels of cholesteryl esters and triacylglycerols are very low in the brain. Several studies have demonstrated that CETP polymorphisms are associated with the risk of dementia including $\mathrm{AD},{ }^{203-206)}$ but the reason underlying this association has not been defined. In the CNS, lecithin: cholesterol acyltransferase (LCAT) ${ }^{207,208)}$ and acyl-coenzyme A : cholesterol acyltransferase $(\text { ACAT) })^{209,210)}$ are also present. These proteins esterify cholesterol that is outside and inside of the cells, respectively. The major source of LCAT in the brain is astocytes, although the mRNA level of LCAT in primary cultured neurons from murine brain was reported to be higher than that in astrocytes. ${ }^{208)}$ LCAT activity in the CSF of $\mathrm{AD}$ patients is $50 \%$ lower than that of control subjects. ${ }^{211)}$ Mammals express two isoforms of ACAT (ACAT1 and ACAT2). ACAT1 has been found in almost all types of cells, but ACAT2 is expressed primarily in the small intestine and hepatocytes. ${ }^{212,213)}$ ACAT1 has recently become of interest in AD research because inhibition of ACAT1 by pharmacological and genetic techniques appears to be a potential therapeutic target for $\mathrm{AD}$ by reducing amyloid pathology and improving cognitive impairment. ${ }^{214,215}$ ) However, essentially all sterol in the adult brain is unesterified cholesterol. ${ }^{24)}$ Thus, the mechanism by which ACAT1 inhibition reduces amyloid plaques remains unknown.

\section{CONCLUSION}

Lipoproteins play important roles in the functions of all cells including neurons and glia. However, many questions remain about the mechanisms of the regulation of lipid metabolism in the CNS. Important areas for future study include: understanding how only HDL-like particles (not VLDL or LDL) control lipid transport among cells of the CNS in contrast to the peripheral circulation and tissues; understanding how apo AI in the CNS is transported from the blood into the CNS; and identification of the non-cholesterol 24-hydroxylase-dependent pathway for excretion of sterol from the CNS. Further investigations are also needed to understand the role of Apo $E \varepsilon 4$ allele in the loss of neuropro- 
tective function and less effective $\mathrm{A} \beta$ clearance, as a risk factor for the development of late-onset AD. Since novel functions of the members of LDL receptor family, especially as signaling receptors, in the CNS have been discovered in recent years, the importance of research on lipid metabolism in the brain is again at the forefront.

Acknowledgement I would like to thank Dr. Jean E. Vance for critical reviewing of the manuscript. This work is supported by Grant-in-Aid for Young Scientists B (No. 22790254) and in part by the Special Coordination Funds for Promoting Science and Technology from the Ministry of Education, Culture, Sports, Science and Technology, Japan and the Mochida Memorial Foundation for Medical and Pharmaceutical Research.

\section{REFERENCES}

1) Eroglu C., Barres B. A., Nature (London), 468, 223-231 (2010).

2) Azevedo F. A., Carvalho L. R., Grinberg L. T., Farfel J. M., Ferretti R. E., Leite R. E., Jacob Filho W., Lent R., Herculano-Houzel S., J. Comp. Neurol., 513, 532-541 (2009).

3) Dietschy J. M., Turley S. D., Curr. Opin. Lipidol., 12, 105-112 (2001).

4) Goritz C., Mauch D. H., Nagler K., Pfrieger F. W., J. Physiol. Paris, 96, 257-263 (2002).

5) Pfrieger F. W., Bioessays, 25, 72 -78 (2003).

6) Vance J. E., Karten B., Hayashi H., Biochem. Soc. Trans., 34, 399403 (2006).

7) Vance J. E., Hayashi H., Biochim. Biophys. Acta, 1801, 806-818 (2010).

8) Wollmer M. A., Biochim. Biophys. Acta, 1801, 762-773 (2010).

9) Vance J. E., Hayashi H., Karten B., Semin. Cell Dev. Biol., 16, 193 212 (2005).

10) Karten B., Peake K. B., Vance J. E., Biochim. Biophys. Acta, 1791, $659-670$ (2009).

11) Burke K. T., Colvin P. L., Myatt L., Graf G. A., Schroeder F., Woollett L. A., J. Lipid Res., 50, 1146-1155 (2009).

12) Porter F. D., Herman G. E., J. Lipid Res., 52, 6-34 (2011).

13) Dietschy J. M., Biol. Chem., 390, 287-293 (2009).

14) Brankatschk M., Eaton S., J. Neurosci., 30, $10441-10447$ (2010).

15) Jurevics H., Morell P., J. Neurochem., 64, 895-901 (1995).

16) Turley S. D., Burns D. K., Dietschy J. M., Am. J. Physiol., 274, E1099-E1105 (1998).

17) Linton M. F., Gish R., Hubl S. T., Butler E., Esquivel C., Bry W. I., Boyles J. K., Wardell M. R., Young S. G., J. Clin. Invest., 88, 270281 (1991).

18) LaDu M. J., Gilligan S. M., Lukens J. R., Cabana V. G., Reardon C. A., Van Eldik L. J., Holtzman D. M., J. Neurochem., 70, 2070-2081 (1998).

19) Xu Q., Li Y., Cyras C., Sanan D. A., Cordell B., J. Biol. Chem., 275, 31770 -31777 (2000).

20) Yu C., Youmans K. L., LaDu M. J., Biochim. Biophys. Acta, 1801, $819-823$ (2010).

21) Harris F. M., Tesseur I., Brecht W. J., Xu Q., Mullendorff K., Chang S., Wyss-Coray T., Mahley R. W., Huang Y., J. Biol. Chem., 279, $3862-3868$ (2004).

22) Minagawa H., Gong J. S., Jung C. G., Watanabe A., Lund-Katz S., Phillips M. C., Saito H., Michikawa M., J. Neurosci. Res., 87, 2498 2508 (2009).

23) Xu Q., Bernardo A., Walker D., Kanegawa T., Mahley R. W., Huang Y., J. Neurosci., 26, 4985-4994 (2006).

24) Dietschy J. M., Turley S. D., J. Lipid Res., 45, 1375-1397 (2004).

25) Nieweg K., Schaller H., Pfrieger F. W., J. Neurochem., 109, 125-134 (2009).

26) Mauch D. H., Nagler K., Schumacher S., Goritz C., Muller E. C., Otto A., Pfrieger F. W., Science, 294, 1354-1357 (2001).

27) Hayashi H., Campenot R. B., Vance D. E., Vance J. E., J. Biol. Chem., 279, 14009-14015 (2004).

28) Beffert U., Stolt P. C., Herz J., J. Lipid Res., 45, $403-409$ (2004).
29) Herz J., Curr. Opin. Lipidol., 20, 190-196 (2009).

30) Bu G., Nat. Rev. Neurosci., 10, 333-344 (2009).

31) Fryer J. D., Demattos R. B., McCormick L. M., O’Dell M. A., Spinner M. L., Bales K. R., Paul S. M., Sullivan P. M., Parsadanian M., Bu G., Holtzman D. M., J. Biol. Chem., 280, 25754-25759 (2005).

32) Liu Q., Zerbinatti C. V., Zhang J., Hoe H. S., Wang B., Cole S. L., Herz J., Muglia L., Bu G., Neuron, 56, 66-78 (2007).

33) Lund E. G., Guileyardo J. M., Russell D. W., Proc. Natl. Acad. Sci. U.S.A., 96, $7238-7243$ (1999).

34) Lund E. G., Xie C., Kotti T., Turley S. D., Dietschy J. M., Russell D. W., J. Biol. Chem., 278, 22980-22988 (2003).

35) Ramirez D. M., Andersson S., Russell D. W., J. Comp. Neurol., 507, 1676-1693 (2008).

36) Russell D. W., Halford R. W., Ramirez D. M., Shah R., Kotti T., Annu. Rev. Biochem., 78, 1017-1040 (2009).

37) Tachikawa M., Watanabe M., Hori S., Fukaya M., Ohtsuki S., Asashima T., Terasaki T., J. Neurochem., 95, 294-304 (2005).

38) Kim W. S., Weickert C. S., Garner B., J. Neurochem., 104, 1145 1166 (2008)

39) Tarr P. T., Edwards P. A., J. Lipid Res., 49, 169-182 (2008).

40) Wang N., Yvan-Charvet L., Lutjohann D., Mulder M., Vanmierlo T., Kim T. W., Tall A. R., FASEB J., 22, 1073-1082 (2008).

41) Wahrle S. E., Jiang H., Parsadanian M., Legleiter J., Han X., Fryer J. D., Kowalewski T., Holtzman D. M., J. Biol. Chem., 279, 4098740993 (2004).

42) Hirsch-Reinshagen V., Zhou S., Burgess B. L., Bernier L., McIsaac S. A., Chan J. Y., Tansley G. H., Cohn J. S., Hayden M. R., Wellington C. L., J. Biol. Chem., 279, 41197-41207 (2004).

43) Karasinska J. M., Rinninger F., Lutjohann D., Ruddle P., Franciosi S., Kruit J. K., Singaraja R. R., Hirsch-Reinshagen V., Fan J., Brunham L. R., Bissada N., Ramakrishnan R., Wellington C. L., Parks J. S., Hayden M. R., J. Neurosci., 29, 3579-3589 (2009).

44) Kennedy M. A., Barrera G. C., Nakamura K., Baldan A., Tarr P., Fishbein M. C., Frank J., Francone O. L., Edwards P. A., Cell Metab., 1, 121-131 (2005).

45) Oldfield S., Lowry C., Ruddick J., Lightman S., Biochim. Biophys. Acta, 1591, 175-179 (2002).

46) Karten B., Campenot R. B., Vance D. E., Vance J. E., J. Biol. Chem., 281, 4049-4057 (2006).

47) Bojanic D. D., Tarr P. T., Gale G. D., Smith D. J., Bok D., Chen B., Nusinowitz S., Lovgren-Sandblom A., Bjorkhem I., Edwards P. A., J. Lipid Res., 51, 169-181 (2010).

48) Uehara Y., Yamada T., Baba Y., Miura S., Abe S., Kitajima K., Higuchi M. A., Iwamoto T., Saku K., Brain Res., 1217, 239-246 (2008).

49) Ladu M. J., Reardon C., Van Eldik L., Fagan A. M., Bu G., Holtzman D., Getz G. S., Ann. N.Y. Acad. Sci., 903, 167-175 (2000).

50) Poirier J., Neurobiol. Aging, 26, 355-361 (2005).

51) Pitas R. E., Boyles J. K., Lee S. H., Hui D., Weisgraber K. H., J. Biol. Chem., 262, 14352-14360 (1987).

52) Fukumoto H., Ingelsson M., Garevik N., Wahlund L. O., Nukina N., Yaguchi Y., Shibata M., Hyman B. T., Rebeck G. W., Irizarry M. C., Exp. Neurol., 183, 249-253 (2003).

53) DeMattos R. B., Brendza R. P., Heuser J. E., Kierson M., Cirrito J. R., Fryer J., Sullivan P. M., Fagan A. M., Han X., Holtzman D. M., Neurochem. Int., 39, 415-425 (2001).

54) Nathan B. P., Nisar R., Randall S., Short J., Sherrow M., Wong G. K., Struble R. G., Exp. Neurol., 172, 128-136 (2001).

55) Ignatius M. J., Gebicke-Harter P. J., Skene J. H., Schilling J. W., Weisgraber K. H., Mahley R. W., Shooter E. M., Proc. Natl. Acad. Sci. U.S.A., 83, 1125-1129 (1986).

56) Snipes G. J., McGuire C. B., Norden J. J., Freeman J. A., Proc. Natl. Acad. Sci. U.S.A., 83, 1130-1134 (1986).

57) Boyles J. K., Notterpek L. M., Anderson L. J., J. Biol. Chem., 265, 17805-17815 (1990).

58) Masliah E., Mallory M., Ge N., Alford M., Veinbergs I., Roses A. D., Exp. Neurol., 136, 107-122 (1995).

59) Gordon I., Genis I., Grauer E., Sehayek E., Michaelson D. M., Mol. Chem. Neuropathol., 28, 97-103 (1996).

60) Masliah E., Samuel W., Veinbergs I., Mallory M., Mante M., Saitoh T., Brain Res., 751, 307-314 (1997).

61) Oitzl M. S., Mulder M., Lucassen P. J., Havekes L. M., Grootendorst J., de Kloet E. R., Brain Res., 752, 189-196 (1997).

62) Horsburgh K., Macrae I. M., Carswell H., J. Cereb. Blood Flow 
Metab., 22, 1189-1195 (2002)

63) Osada N., Kosuge Y., Kihara T., Ishige K., Ito Y., Neurochem. Int., 54, 403-409 (2009).

64) Valenza M., Rigamonti D., Goffredo D., Zuccato C., Fenu S., Jamot L., Strand A., Tarditi A., Woodman B., Racchi M., Mariotti C., Di Donato S., Corsini A., Bates G., Pruss R., Olson J. M., Sipione S., Tartari M., Cattaneo E., J. Neurosci., 25, 9932 -9939 (2005).

65) Valenza M., Leoni V., Karasinska J. M., Petricca L., Fan J., Carroll J., Pouladi M. A., Fossale E., Nguyen H. P., Riess O., MacDonald M., Wellington C., DiDonato S., Hayden M., Cattaneo E., J. Neurosci., 30, $10844-10850$ (2010)

66) Matsuo M., Campenot R. B., Vance D. E., Ueda K., Vance J. E., Biochim. Biophys. Acta, 1811, 31-38 (2011).

67) Leoni V., Solomon A., Kivipelto M., Biochem. Soc. Trans., 38, $1021-1025$ (2010)

68) LaDu M. J., Shah J. A., Reardon C. A., Getz G. S., Bu G., Hu J., Guo L., Van Eldik L. J., Neurochem. Int., 39, 427-434 (2001).

69) Hayashi H., Campenot R. B., Vance D. E., Vance J. E., J. Neurosci., 27, 1933-1941 (2007).

70) Hayashi H., Campenot R. B., Vance D. E., Vance J. E., J. Biol. Chem., 284, 29605-29613 (2009)

71) de Silva H. V., Harmony J. A., Stuart W. D., Gil C. M., Robbins J., Biochemistry, 29, 5380-5389 (1990).

72) Fagan A. M., Holtzman D. M., Munson G., Mathur T., Schneider D., Chang L. K., Getz G. S., Reardon C. A., Lukens J., Shah J. A., LaDu M. J., J. Biol. Chem., 274, 30001-30007 (1999).

73) Montpied P., de Bock F., Baldy-Moulinier M., Rondouin G., Neuroreport, 9, 79-83 (1998).

74) White F., Nicoll J. A., Horsburgh K., Exp. Neurol., 169, 307-318 (2001).

75) Strocchi P., Rauzi F., Cevolani D., Neuroreport, 10, 1789-1792 (1999).

76) Charnay Y., Imhof A., Vallet P. G., Hakkoum D., Lathuiliere A., Poku N., Aronow B., Kovari E., Bouras C., Giannakopoulos P., Neuroscience, 155, 714-724 (2008).

77) Imhof A., Charnay Y., Vallet P. G., Aronow B., Kovari E., French L. E., Bouras C., Giannakopoulos P., Neurobiol. Dis., 22, 274-283 (2006).

78) Wicher G. K., Aldskogius H., Eur. J. Neurosci., 21, 2024-2028 (2005).

79) Han B. H., DeMattos R. B., Dugan L. L., Kim-Han J. S., Brendza R. P., Fryer J. D., Kierson M., Cirrito J., Quick K., Harmony J. A., Aronow B. J., Holtzman D. M., Nat. Med., 7, 338-343 (2001).

80) Yang C. R., Leskov K., Hosley-Eberlein K., Criswell T., Pink J. J., Kinsella T. J., Boothman D. A., Proc. Natl. Acad. Sci. U.S.A., 97, 5907-5912 (2000).

81) Shin Y. J., Kang S. W., Jeong S. Y., Shim Y. J., Kim Y. H., Kim B. M., Kee S. H., Park J. J., Park I. S., Min B. H., Neuroreport, 17, 1871-1875 (2006)

82) Bento-Abreu A., Velasco A., Polo-Hernandez E., Perez-Reyes P. L., Tabernero A., Medina J. M., J. Neurochem., 106, 1149-1159 (2008).

83) Rassart E., Bedirian A., Do Carmo S., Guinard O., Sirois J., Terrisse L., Milne R., Biochim. Biophys. Acta, 1482, 185-198 (2000).

84) Kosacka J., Gericke M., Nowicki M., Kacza J., Borlak J., SpanelBorowski K., Neuroscience, 162, 282-291 (2009)

85) Thomas E. A., Laws S. M., Sutcliffe J. G., Harper C., Dean B., McClean C., Masters C., Lautenschlager N., Gandy S. E., Martins R. N. Biol. Psychiatry, 54, 136-141 (2003).

86) Suresh S., Yan Z., Patel R. C., Patel Y. C., Patel S. C., J. Neurochem., 70, 242-251 (1998).

87) Rickhag M., Wieloch T., Gido G., Elmer E., Krogh M., Murray J., Lohr S., Bitter H., Chin D. J., von Schack D., Shamloo M., Nikolich K., J. Neurochem., 96, 14-29 (2006).

88) Rickhag M., Deierborg T., Patel S., Ruscher K., Wieloch T., J. Cereb. Blood Flow Metab., 28, 551-562 (2008).

89) Ruscher K., Johannesson E., Brugiere E., Erickson A., Rickhag M., Wieloch T., J. Cereb. Blood Flow Metab., 29, 1796-1805 (2009).

90) Terrisse L., Seguin D., Bertrand P., Poirier J., Milne R., Rassart E., Brain Res. Mol. Brain Res., 70, 26-35 (1999).

91) Balazs Z., Panzenboeck U., Hammer A., Sovic A., Quehenberger O., Malle E., Sattler W., J. Neurochem., 89, 939-950 (2004).

92) Lewis T. L., Cao D., Lu H., Mans R. A., Su Y. R., Jungbauer L., Linton M. F., Fazio S., LaDu M. J., Li L., J. Biol. Chem., 285, 36958 36968 (2010)
93) Lefterov I., Fitz N. F., Cronican A. A., Fogg A., Lefterov P., Kodali R., Wetzel R., Koldamova R., J. Biol. Chem., 285, 36945-36957 (2010).

94) Huang J. T., Wang L., Prabakaran S., Wengenroth M., Lockstone H. E., Koethe D., Gerth C. W., Gross S., Schreiber D., Lilley K., Wayland M., Oxley D., Leweke F. M., Bahn S., Mol. Psychiatry, 13, 1118 - 1128 (2008).

95) Rebeck G. W., LaDu M. J., Estus S., Bu G., Weeber E. J., Mol. Neurodegener., 1, 15 (2006).

96) Herz J., Chen Y., Masiulis I., Zhou L., J. Lipid Res., 50 (Suppl.), S287-S292 (2009)

97) Boucher P., Herz J., Biochem. Pharmacol., 81, 1-5 (2011).

98) Qiu Z., Strickland D. K., Hyman B. T., Rebeck G. W., J. Biol. Chem., 277, 14458-14466 (2002).

99) May P., Rohlmann A., Bock H. H., Zurhove K., Marth J. D., Schomburg E. D., Noebels J. L., Beffert U., Sweatt J. D., Weeber E. J., Herz J., Mol. Cell. Biol., 24, 8872-8883 (2004).

100) Fuentealba R. A., Liu Q., Kanekiyo T., Zhang J., Bu G., J. Biol. Chem., 284, 34045-34053 (2009).

101) Shi Y., Mantuano E., Inoue G., Campana W. M., Gonias S. L., Sci. Signal., 2, ra18 (2009).

102) Herz J., Clouthier D. E., Hammer R. E., Cell, 71, 411-421 (1992).

103) Liu Q., Trotter J., Zhang J., Peters M. M., Cheng H., Bao J., Han X., Weeber E. J., Bu G., J. Neurosci., 30, 17068-17078 (2010)

104) Herz J., Chen Y., Nat. Rev. Neurosci., 7, 850-859 (2006).

105) Dieckmann M., Dietrich M. F., Herz J., Biol. Chem., 391, 1341$1363(2010)$

106) Trommsdorff M., Gotthardt M., Hiesberger T., Shelton J., Stockinger W., Nimpf J., Hammer R. E., Richardson J. A., Herz J., Cell, 97, 689-701 (1999).

107) D'Arcangelo G., Homayouni R., Keshvara L., Rice D. S., Sheldon M., Curran T., Neuron, 24, 471—479 (1999).

108) Tueting P., Doueiri M. S., Guidotti A., Davis J. M., Costa E., Neurosci. Biobehav. Rev., 30, 1065-1077 (2006).

109) Knuesel I., Prog. Neurobiol., 91, 257-274 (2010).

110) Frotscher M., Trends Neurosci., 33, 407-414 (2010).

111) Blake S. M., Strasser V., Andrade N., Duit S., Hofbauer R., Schneider W. J., Nimpf J., EMBO J., 27, 3069-3080 (2008).

112) Kounnas M. Z., Loukinova E. B., Stefansson S., Harmony J. A., Brewer B. H., Strickland D. K., Argraves W. S., J. Biol. Chem., 270, 13070-13075 (1995).

113) Zlokovic B. V., Martel C. L., Matsubara E., McComb J. G., Zheng G., McCluskey R. T., Frangione B., Ghiso J., Proc. Natl. Acad. Sci. U.S.A., 93, 4229-4234 (1996).

114) Chung R. S., Penkowa M., Dittmann J., King C. E., Bartlett C., Asmussen J. W., Hidalgo J., Carrasco J., Leung Y. K., Walker A. K., Fung S. J., Dunlop S. A., Fitzgerald M., Beazley L. D., Chuah M. I., Vickers J. C., West A. K., J. Biol. Chem., 283, 15349-15358 (2008).

115) Alvira-Botero X., Perez-Gonzalez R., Spuch C., Vargas T., Antequera D., Garzon M., Bermejo-Pareja F., Carro E., Mol. Cell. Neurosci., 45, 306-315 (2010).

116) Willnow T. E., Hilpert J., Armstrong S. A., Rohlmann A., Hammer R. E., Burns D. K., Herz J., Proc. Natl. Acad. Sci. U.S.A., 93, 84608464 (1996)

117) Kantarci S., Al-Gazali L., Hill R. S., Donnai D., Black G. C., Bieth E., Chassaing N., Lacombe D., Devriendt K., Teebi A., Loscertales M., Robson C., Liu T., MacLaughlin D. T., Noonan K. M., Russell M. K., Walsh C. A., Donahoe P. K., Pober B. R., Nat. Genet., 39, 957-959 (2007).

118) Hermey G., Cell. Mol. Life Sci., 66, 2677-2689 (2009)

119) Morwald S., Yamazaki H., Bujo H., Kusunoki J., Kanaki T., Seimiya K., Morisaki N., Nimpf J., Schneider W. J., Saito Y., Arterioscler Thromb. Vasc. Biol., 17, 996-1002 (1997).

120) Yamazaki H., Bujo H., Saito Y., J. Atheroscler. Thromb., 4, 20-26 (1997).

121) Motoi Y., Aizawa T., Haga S., Nakamura S., Namba Y., Ikeda K., Brain Res., 833, 209-215 (1999)

122) Posse De Chaves E. I., Vance D. E., Campenot R. B., Kiss R. S., Vance J. E., J. Biol. Chem., 275, 19883-19890 (2000).

123) Spoelgen R., Adams K. W., Koker M., Thomas A. V., Andersen O. M., Hallett P. J., Bercury K. K., Joyner D. F., Deng M., Stoothoff W. H., Strickland D. K., Willnow T. E., Hyman B. T., Neuroscience, 158 , $1460-1468$ (2009).

124) Willnow T. E., Carlo A. S., Rohe M., Schmidt V., Rev. Neurosci., 21 , 
$315-329$ (2010).

125) Jaeger S., Pietrzik C. U., Curr. Alzheimer Res., 5, 15-25 (2008).

126) Hooijmans C. R., Kiliaan A. J., Eur. J. Pharmacol., 585, 176-196 (2008).

127) Martins I. J., Berger T., Sharman M. J., Verdile G., Fuller S. J., Martins R. N., J. Neurochem., 111, 1275-1308 (2009).

128) Grosgen S., Grimm M. O., Friess P., Hartmann T., Biochim. Biophys. Acta, 1801, 966-974 (2010).

129) Jones L., Harold D., Williams J., Biochim. Biophys. Acta, 1801, 754-761 (2010).

130) Poirier J., Alzheimers Dement., 4, S91—S97 (2008).

131) Kim J., Basak J. M., Holtzman D. M., Neuron, 63, 287-303 (2009).

132) Zhong N., Weisgraber K. H., J. Biol. Chem., 284, 6027-6031 (2009).

133) Huang Y., Trends Mol. Med., 16, 287-294 (2010).

134) Iurescia S., Fioretti D., Mangialasche F., Rinaldi M., J. Alzheimers Dis., 21, 35- 48 (2010)

135) Strittmatter W. J., Saunders A. M., Schmechel D., Pericak-Vance M., Enghild J., Salvesen G. S., Roses A. D., Proc. Natl. Acad. Sci. U.S.A., 90, 1977-1981 (1993).

136) Corder E. H., Saunders A. M., Risch N. J., Strittmatter W. J., Schmechel D. E., Gaskell P. C. Jr., Rimmler J. B., Locke P. A., Conneally P. M., Schmader K. E., Small G. W., Roses A. D., Haines J. L., Pericak-Vance M. A., Nat. Genet., 7, 180-184 (1994).

137) Rebeck G. W., Reiter J. S., Strickland D. K., Hyman B. T., Neuron, 11, 575-580 (1993).

138) Schmechel D. E., Saunders A. M., Strittmatter W. J., Crain B. J., Hulette C. M., Joo S. H., Pericak-Vance M. A., Goldgaber D., Roses A. D., Proc. Natl. Acad. Sci. U.S.A., 90, 9649-9653 (1993).

139) Reiman E. M., Chen K., Liu X., Bandy D., Yu M., Lee W., Ayutyanont N., Keppler J., Reeder S. A., Langbaum J. B., Alexander G. E., Klunk W. E., Mathis C. A., Price J. C., Aizenstein H. J., DeKosky S. T., Caselli R. J., Proc. Natl. Acad. Sci. U.S.A., 106, $6820-6825$ (2009).

140) LaDu M. J., Falduto M. T., Manelli A. M., Reardon C. A., Getz G. S., Frail D. E., J. Biol. Chem., 269, 23403-23406 (1994).

141) Yang D. S., Smith J. D., Zhou Z., Gandy S. E., Martins R. N., J. Neurochem., 68, 721-725 (1997).

142) Deane R., Sagare A., Hamm K., Parisi M., Lane S., Finn M. B., Holtzman D. M., Zlokovic B. V., J. Clin. Invest., 118, 4002-4013 (2008).

143) Shibata M., Yamada S., Kumar S. R., Calero M., Bading J., Frangione B., Holtzman D. M., Miller C. A., Strickland D. K., Ghiso J., Zlokovic B. V., J. Clin. Invest., 106, 1489-1499 (2000).

144) Pflanzner T., Janko M. C., Andre-Dohmen B., Reuss S., Weggen S., Roebroek A. J., Kuhlmann C. R., Pietrzik C. U., Neurobiol. Aging (in press).

145) Zlokovic B. V., Deane R., Sagare A. P., Bell R. D., Winkler E. A., J. Neurochem., 115, 1077-1089 (2010)

146) Matsubara E., Frangione B., Ghiso J., J. Biol. Chem., 270, 75637567 (1995)

147) Choi-Miura N. H., Ihara Y., Fukuchi K., Takeda M., Nakano Y., Tobe T., Tomita M., Acta Neuropathol., 83, 260-264 (1992).

148) May P. C., Lampert-Etchells M., Johnson S. A., Poirier J., Masters J. N., Finch C. E., Neuron, 5, 831-839 (1990).

149) Oda T., Pasinetti G. M., Osterburg H. H., Anderson C., Johnson S. A., Finch C. E., Biochem. Biophys. Res. Commun., 204, 1131-1136 (1994).

150) Boggs L. N., Fuson K. S., Baez M., Churgay L., McClure D., Becker G., May P. C., J. Neurochem., 67, 1324-1327 (1996).

151) DeMattos R. B., O’Dell M. A., Parsadanian M., Taylor J. W., Harmony J. A., Bales K. R., Paul S. M., Aronow B. J., Holtzman D. M., Proc. Natl. Acad. Sci. U.S.A., 99, 10843-10848 (2002).

152) Lambert J. C., Heath S., Even G., Campion D., Sleegers K., Hiltunen M., Combarros O., Zelenika D., Bullido M. J., Tavernier B., Letenneur L., Bettens K., Berr C., Pasquier F., Fievet N., Barberger-Gateau P., Engelborghs S., De Deyn P., Mateo I., Franck A., Helisalmi S., Porcellini E., Hanon O., de Pancorbo M. M., Lendon C., Dufouil C., Jaillard C., Leveillard T., Alvarez V., Bosco P., Mancuso M., Panza F., Nacmias B., Bossu P., Piccardi P., Annoni G., Seripa D., Galimberti D., Hannequin D., Licastro F., Soininen H., Ritchie K., Blanche H., Dartigues J. F., Tzourio C., Gut I., Van Broeckhoven C., Alperovitch A., Lathrop M., Amouyel P., Nat. Genet., 41, 1094-1099 (2009).

153) Thomas E. A., Sautkulis L. N., Criado J. R., Games D., Sutcliffe J.
G., J. Neurochem., 79, 1059-1064 (2001).

154) Terrisse L., Poirier J., Bertrand P., Merched A., Visvikis S., Siest G., Milne R., Rassart E., J. Neurochem., 71, 1643-1650 (1998).

155) Belloir B., Kovari E., Surini-Demiri M., Savioz A., J. Neurosci. Res., 64, 61-69 (2001)

156) Kalman J., McConathy W., Araoz C., Kasa P., Lacko A. G., Neurol. Res., 22, 330-336 (2000).

157) del Valle E., Navarro A., Astudillo A., Tolivia J., J. Histochem. Cytochem., 51, 1285-1290 (2003).

158) Navarro A., Del Valle E., Astudillo A., Gonzalez del Rey C., Tolivia J., Exp. Neurol., 184, 697-704 (2003).

159) Chen Y., Jia L., Wei C., Wang F., Lv H., Jia J., Brain Res., 1233, 196-202 (2008).

160) Desai P. P., Hendrie H. C., Evans R. M., Murrell J. R., DeKosky S. T., Kamboh M. I., Am. J. Med. Genet. B Neuropsychiatr. Genet., 116B, 98-101 (2003).

161) Helisalmi S., Hiltunen M., Vepsalainen S., Iivonen S., Corder E. H., Lehtovirta M., Mannermaa A., Koivisto A. M., Soininen H., J. Neurol., 251, 951-957 (2004).

162) Fagan A. M., Christopher E., Taylor J. W., Parsadanian M., Spinner M., Watson M., Fryer J. D., Wahrle S., Bales K. R., Paul S. M., Holtzman D. M., Am. J. Pathol., 165, 1413-1422 (2004).

163) Vollbach H., Heun R., Morris C. M., Edwardson J. A., McKeith I. G., Jessen F., Schulz A., Maier W., Kolsch H., Ann. Neurol., 58, 436441 (2005).

164) Kalaany N. Y., Mangelsdorf D. J., Annu. Rev. Physiol., 68, 159—191 (2006).

165) Zelcer N., Khanlou N., Clare R., Jiang Q., Reed-Geaghan E. G., Landreth G. E., Vinters H. V., Tontonoz P., Proc. Natl. Acad. Sci. U.S.A., 104, 10601-10606 (2007).

166) Riddell D. R., Zhou H., Comery T. A., Kouranova E., Lo C. F., Warwick H. K., Ring R. H., Kirksey Y., Aschmies S., Xu J., Kubek K., Hirst W. D., Gonzales C., Chen Y., Murphy E., Leonard S., Vasylyev D., Oganesian A., Martone R. L., Pangalos M. N., Reinhart P. H., Jacobsen J. S., Mol. Cell. Neurosci., 34, 621-628 (2007).

167) Fitz N. F., Cronican A., Pham T., Fogg A., Fauq A. H., Chapman R., Lefterov I., Koldamova R., J. Neurosci., 30, 6862 -6872 (2010).

168) Jiang Q., Lee C. Y., Mandrekar S., Wilkinson B., Cramer P., Zelcer N., Mann K., Lamb B., Willson T. M., Collins J. L., Richardson J. C., Smith J. D., Comery T. A., Riddell D., Holtzman D. M., Tontonoz P., Landreth G. E., Neuron, 58, 681-693 (2008).

169) Marzolo M. P., Bu G., Semin. Cell Dev. Biol., 20, 191-200 (2009).

170) Marks N., Berg M. J., Neurochem. Res., 35, 181-210 (2010).

171) Rogaeva E., Meng Y., Lee J. H., Gu Y., Kawarai T., Zou F., Katayama T., Baldwin C. T., Cheng R., Hasegawa H., Chen F., Shibata N., Lunetta K. L., Pardossi-Piquard R., Bohm C., Wakutani Y., Cupples L. A., Cuenco K. T., Green R. C., Pinessi L., Rainero I., Sorbi S., Bruni A., Duara R., Friedland R. P., Inzelberg R., Hampe W., Bujo H., Song Y. Q., Andersen O. M., Willnow T. E., Graff-Radford N., Petersen R. C., Dickson D., Der S. D., Fraser P. E., Schmitt-Ulms G., Younkin S., Mayeux R., Farrer L. A., St George-Hyslop P., Nat. Genet., 39, 168-177 (2007).

172) Dodson S. E., Andersen O. M., Karmali V., Fritz J. J., Cheng D., Peng J., Levey A. I., Willnow T. E., Lah J. J., J. Neurosci., 28, $12877-$ 12886 (2008).

173) Scherzer C. R., Offe K., Gearing M., Rees H. D., Fang G., Heilman C. J., Schaller C., Bujo H., Levey A. I., Lah J. J., Arch. Neurol., 61, $1200-1205$ (2004).

174) Dodson S. E., Gearing M., Lippa C. F., Montine T. J., Levey A. I., Lah J. J., J. Neuropathol. Exp. Neurol., 65, 866-872 (2006).

175) Sager K. L., Wuu J., Leurgans S. E., Rees H. D., Gearing M., Mufson E. J., Levey A. I., Lah J. J., Ann. Neurol., 62, 640 - 647 (2007).

176) Ma Q. L., Galasko D. R., Ringman J. M., Vinters H. V., Edland S. D., Pomakian J., Ubeda O. J., Rosario E. R., Teter B., Frautschy S. A., Cole G. M., Arch. Neurol., 66, 448-457 (2009).

177) Andersen O. M., Reiche J., Schmidt V., Gotthardt M., Spoelgen R., Behlke J., von Arnim C. A., Breiderhoff T., Jansen P., Wu X., Bales K. R., Cappai R., Masters C. L., Gliemann J., Mufson E. J., Hyman B. T., Paul S. M., Nykjaer A., Willnow T. E., Proc. Natl. Acad. Sci. U.S.A., 102, 13461-13466 (2005).

178) Andersen O. M., Schmidt V., Spoelgen R., Gliemann J., Behlke J., Galatis D., McKinstry W. J., Parker M. W., Masters C. L., Hyman B. T., Cappai R., Willnow T. E., Biochemistry, 45, 2618-2628 (2006).

179) Spoelgen R., von Arnim C. A., Thomas A. V., Peltan I. D., Koker M., 
Deng A., Irizarry M. C., Andersen O. M., Willnow T. E., Hyman B. T., J. Neurosci., 26, 418-428 (2006).

180) Offe K., Dodson S. E., Shoemaker J. T., Fritz J. J., Gearing M., Levey A. I., Lah J. J., J. Neurosci., 26, 1596-1603 (2006).

181) Ma Q. L., Teter B., Ubeda O. J., Morihara T., Dhoot D., Nyby M. D., Tuck M. L., Frautschy S. A., Cole G. M., J. Neurosci., 27, 1429914307 (2007)

182) Cederholm T., Palmblad J., Curr. Opin. Clin. Nutr. Metab. Care, 13, $150-155$ (2010).

183) Yamada K., Hashimoto T., Yabuki C., Nagae Y., Tachikawa M., Strickland D. K., Liu Q., Bu G., Basak J. M., Holtzman D. M., Ohtsuki S., Terasaki T., Iwatsubo T., J. Biol. Chem., 283, 34554-34562 (2008).

184) Fuentealba R. A., Liu Q., Zhang J., Kanekiyo T., Hu X., Lee J. M., LaDu M. J., Bu G., PLoS One, 5, e1 1884 (2010).

185) Waldron E., Heilig C., Schweitzer A., Nadella N., Jaeger S., Martin A. M., Weggen S., Brix K., Pietrzik C. U., Neurobiol. Dis., 31, 188197 (2008).

186) Blacker D., Wilcox M. A., Laird N. M., Rodes L., Horvath S. M., Go R. C., Perry R., Watson B. Jr., Bassett S. S., McInnis M. G., Albert M. S., Hyman B. T., Tanzi R. E., Nat. Genet., 19, 357-360 (1998).

187) Tanzi R. E., Bertram L., Neuron, 32, 181-184 (2001).

188) Lambert J. C., Wavrant-De Vrieze F., Amouyel P., Chartier-Harlin M. C., Lancet, 351, 1787-1788 (1998).

189) Hollenbach E., Ackermann S., Hyman B. T., Rebeck G. W., Neurology, 50, 1905-1907 (1998).

190) Scott W. K., Yamaoka L. H., Bass M. P., Gaskell P. C., Conneally P. M., Small G. W., Farrer L. A., Auerbach S. A., Saunders A. M., Roses A. D., Haines J. L., Pericak-Vance M. A., Neurogenetics, 1, 179-183 (1998).

191) Sanchez-Guerra M., Combarros O., Infante J., Llorca J., Berciano J., Fontalba A., Fernandez-Luna J. L., Pena N., Fernandez-Viadero C., Neurosci. Lett., 316, 17-20 (2001).

192) Pritchard A., Harris J., Pritchard C. W., St Clair D., Lemmon H., Lambert J. C., Chartier-Harlin M. C., Hayes A., Thaker U., Iwatsubo T., Mann D. M., Lendon C., Neurosci. Lett., 382, 221-226 (2005).

193) Husemann J., Loike J. D., Anankov R., Febbraio M., Silverstein S. C., Glia, 40, 195-205 (2002).

194) Alarcon R., Fuenzalida C., Santibanez M., von Bernhardi R., J. Biol. Chem., 280, 30406-30415 (2005).

195) Thanopoulou K., Fragkouli A., Stylianopoulou F., Georgopoulos S., Proc. Natl. Acad. Sci. U.S.A., 107, 20816-20821 (2010).

196) Chang E. H., Rigotti A., Huerta P. T., Neurobiol. Aging, 30, 407419 (2009).

197) Gander R., Eller P., Kaser S., Theurl I., Walter D., Sauper T., Ritsch
A., Patsch J. R., Foger B., J. Lipid Res., 43, 636-645 (2002).

198) Vuletic S., Jin L. W., Marcovina S. M., Peskind E. R., Moller T., Albers J. J., J. Lipid Res., 44, 1113-1123 (2003).

199) Jiang X. C., Zhou H. W., Curr. Opin. Lipidol., 17, 302-308 (2006).

200) Vuletic S., Peskind E. R., Marcovina S. M., Quinn J. F., Cheung M. C., Kennedy H., Kaye J. A., Jin L. W., Albers J. J., J. Neurosci. Res., 80, 406- 413 (2005).

201) Albers J. J., Tollefson J. H., Wolfbauer G., Albright R. E. Jr., Int. J. Clin. Lab. Res., 21, 264-266 (1992).

202) Yamada T., Kawata M., Arai H., Fukasawa M., Inoue K., Sato T., Acta Neuropathol., 90, 633-636 (1995).

203) Zhu H., Gopalraj R. K., Kelly J. F., Bennett D. A., Estus S., Neurosci. Lett., 381, 36- 41 (2005)

204) Arias-Vasquez A., Isaacs A., Aulchenko Y. S., Hofman A., Oostra B. A., Breteler M., van Duijn C. M., Neurogenetics, 8, 189-193 (2007).

205) Qureischie H., Heun R., Lutjohann D., Popp J., Jessen F., LedschborFrahnert C., Thiele H., Maier W., Hentschel F., Kelemen P., Kolsch H., Brain Res., 1232, $1-6$ (2008).

206) Sanders A. E., Wang C., Katz M., Derby C. A., Barzilai N., Ozelius L., Lipton R. B., JAMA, 303, 150-158 (2010).

207) Collet X., Francone O., Besnard F., Fielding C. J., Biochem. Biophys. Res. Commun., 258, 73-76 (1999).

208) Hirsch-Reinshagen V., Donkin J., Stukas S., Chan J., Wilkinson A., Fan J., Parks J. S., Kuivenhoven J. A., Lutjohann D., Pritchard H., Wellington C. L., J. Lipid Res., 50, 885-893 (2009).

209) Sakashita N., Miyazaki A., Takeya M., Horiuchi S., Chang C. C., Chang T. Y., Takahashi K., Am. J. Pathol., 156, 227-236 (2000).

210) Huttunen H. J., Kovacs D. M., Neurodegener. Dis., 5, 212-214 (2008).

211) Demeester N., Castro G., Desrumaux C., De Geitere C., Fruchart J. C., Santens P., Mulleners E., Engelborghs S., De Deyn P. P., Vandekerckhove J., Rosseneu M., Labeur C., J. Lipid Res., 41, 963974 (2000).

212) Chang T. Y., Li B. L., Chang C. C., Urano Y., Am. J. Physiol. Endocrinol. Metab., 297, E1-E9 (2009)

213) Bhattacharyya R., Kovacs D. M., Biochim. Biophys. Acta, 1801, 960-965 (2010).

214) Puglielli L., Konopka G., Pack-Chung E., Ingano L. A., Berezovska O., Hyman B. T., Chang T. Y., Tanzi R. E., Kovacs D. M., Nat. Cell. Biol., 3, 905-912 (2001).

215) Bryleva E. Y., Rogers M. A., Chang C. C., Buen F., Harris B. T., Rousselet E., Seidah N. G., Oddo S., LaFerla F. M., Spencer T. A., Hickey W. F., Chang T. Y., Proc. Natl. Acad. Sci. U.S.A., 107, 30813086 (2010). 